\title{
Private Equity and Industry Performance
}

\author{
Bernstein, Shai; Lerner, Josh; Sørensen, Morten; Strömberg, Per
}

Document Version

Accepted author manuscript

Published in:

Management Science

DOI:

$10.1287 / \mathrm{mnsc} .2015 .2404$

Publication date:

2017

License

Unspecified

Citation for published version (APA):

Bernstein, S., Lerner, J., Sørensen, M., \& Strömberg, P. (2017). Private Equity and Industry Performance. Management Science, 63(4), 1198-1213. https://doi.org/10.1287/mnsc.2015.2404

Link to publication in CBS Research Portal

\section{General rights}

Copyright and moral rights for the publications made accessible in the public portal are retained by the authors and/or other copyright owners and it is a condition of accessing publications that users recognise and abide by the legal requirements associated with these rights.

Take down policy

If you believe that this document breaches copyright please contact us (research.lib@cbs.dk) providing details, and we will remove access to the work immediately and investigate your claim. 


\section{Private Equity and Industry Performance}

\section{Shai Bernstein, Josh Lerner, Morten Serensen, and Per Strömberg}

Journal article (Accepted version)

CITE: Private Equity and Industry Performance. / Bernstein, Shai; Lerner, Josh; Sørensen, Morten; Strömberg, Per. In: Management Science, Vol. 63, No. 4, 03.2017, p. 1198-1213.

DOI: 10.1287/mnsc.2015.2404

Uploaded to Research@CBS: January २०18 


\title{
Private Equity and Industry Performance
}

\author{
Shai Bernstein, Stanford University and NBER \\ Josh Lerner, Harvard University and NBER \\ Morten Sorensen, Columbia Business School and NBER \\ Per Strömberg, Stockholm School of Economics, SIFR, and CEPR
}

\begin{abstract}
The growth of the private equity industry has spurred concerns about its impact on the economy. This analysis looks across nations and industries to assess the impact of private equity on industry performance. We find that industries where private equity funds invest grow more quickly in terms of total production and employment, and appear less exposed to aggregate shocks. Our robustness tests provide some evidence that is consistent with our effects being driven by our preferred channel.
\end{abstract}

JEL: G23, G24, G28, G32, G34

Keywords: Private Equity, Industry Growth, Cross-Country Analysis, Production, Employment, Instrumental Variables 


\section{Introduction}

In response to the global financial crisis that began in 2007, governments are rethinking their approach to regulating financial institutions, with private equity (PE) funds in particular being targeted by regulators. Most dramatically, in 2010 the European Commission adopted the Alternative Investment Fund Managers directive (European Commission 2010), which contains a sweeping set of rules regulating the PE industry. A variety of other measures, including the Dodd-Frank Act in the United States and European Union's Solvency II directive, have also had substantial implications for private equity funds and their investors.

Regulators, politicians, and labor organizers have long expressed concern about the impact of PE funds, pointing to their need to rapidly return capital to investors and the potentially deleterious effects of such practices as the extensive leveraging of firms. Critics have pointed to case studies that illustrate the negative consequences of the transactions. For instance, Rasmussen (2008) points to the buyout of Britain's Automobile Association, which led to largescale layoffs and service disruptions while generating substantial profits for the transaction's sponsor, Permira. The Service Employees International Union $(2007,2008)$ presents studies that show the deleterious effect that excessive leverage, cost-cutting, and poor managerial decisions by PE groups can have on firms and industries in cases such as Hawaiian Telecom, Intelsat, KB Toys, and TDC. The frequent discussions during the 2012 U.S. presidential election of layoffs and bankruptcies at companies under the control of Bain Capital provide another example.

A central hypothesis in the finance literature since Jensen (1989), however, has been that PE has the ability to improve the operations of firms. By closely monitoring managers, restricting free cash flow through the use of leverage, and incentivizing managers with equity, it is argued, PE-backed firms are able to improve operations in the firms they finance. 
Several case and clinical studies illustrate Jensen's (1989) hypothesis. For instance, in the Hertz buyout, the PE investor Clayton, Dubilier \& Rice (CD\&R) addressed inefficiencies in preexisting operations procedures to help increase the profitability of Hertz. Specifically, CD\&R created value by lowering overhead costs, reducing inefficient labor expenses, cutting noncapital investments down to industry standard levels, and aligning managerial incentives with return on capital (Luehrman 2007). Similarly, the buyout of O.M. Scott \& Sons led to substantial operating improvements in the firm's existing operations, in part due to powerful management incentives, as well as the active involvement by the PE investors (Baker and Wruck 1989).

This paper investigates these conflicting views of the impact of PE investments on aggregate growth and cyclicality. ${ }^{1}$ Specifically, we examine the relationship between the presence of PE investments and the growth rates of total production, employment, and capital formation across 20 industries in 26 major nations between 1991 and 2009. The magnitude of PE investments is substantial: in a given year and country, we estimate that approximately $4 \%$ of the average industry is acquired by PE investors, measured in terms of sales, which is significant given a median holding period of more than five years of these investments. ${ }^{2}$

For our production and employment measures, we find that PE investments are associated with faster growth. Industries where PE funds have been active in the past five years grow more rapidly than other industries, whether measured using total production, value added, total wages, or employment. One concern is that this growth may come at the expense of greater cyclicality, which could translate into greater risks for investors and stakeholders. Thus, we also examine whether economic fluctuations are exacerbated by the presence of PE investments, but

\footnotetext{
${ }^{1}$ While we do not examine spillovers per se, this paper is also related to a large literature examining spillover effects of foreign direct investments and/or multinational companies' presence on the local firms and the economy. Much of this literature is summarized in Blomström and Kokko (1998).

${ }^{2}$ See Strömberg (2008).
} 
we find little evidence that this is the case. Activity in industries with PE backing appears to be on average no more volatile in the face of industry cycles than in other industries, and sometimes less so. In particular, we find that PE investments are particularly related to reduced downside risk of shocks to industry growth rates. The reduced volatility is particularly apparent in total wages. These patterns continue to hold when we focus on the impact of PE in Continental Europe, where concerns about these investments have been most often expressed.

In our baseline empirical specifications, we include country-industry and industry-year fixed effects (FEs), so the impact of PE activity is measured relative to the average performance in a given country, industry, and year. For instance, if the Swedish steel industry has more PE investment than the Finnish one, we examine whether the steel industry in these two countries performs better or worse over time relative to the average performance of the steel industry across all the countries in our sample, and whether the variations in performance over the industry cycles are more or less pronounced.

Another concern is that these results may be driven by reverse causality, i.e., that PE funds select to invest in industries that are growing faster and/or are less volatile. Note that it is not necessarily more profitable to invest in growing industries, if this growth is anticipated and incorporated into the acquisition price. For this market-timing strategy to be profitable, PE investors would have to foresee future industry growth better than the market. Moreover, our data shows that PE investments are overrepresented in mature and traditional industries. While we cannot address this concern in a definitive manner because there is little random variation associated with PE investments, we investigate the causality of our results in several ways. First, our results are essentially unchanged when we exclude PE investments in the previous year, and only consider PE investments made two to five years earlier. Hence, if our results reflect PE 
investors foreseeing future growth, PE investors must be quite farsighted. Second, the results continue to hold when we use an instrumental variables technique, employing the size of the private pension and insurance company asset pool in the nation and year as an instrumental variable. These tests provide some evidence that is consistent with our effects being driven by our preferred channel rather than with reverse causality. ${ }^{3}$

This paper is related to the modest and mixed literature on the competitive effects of PE. Chevalier (1995a, 1995b) shows that buyouts of supermarket chains lead to positive outcomes for local rivals. These rivals are more likely to enter or expand in an urban region, if there are a number of firms that have undergone buyouts and charge higher prices in these markets. She suggests that these results are consistent with "softer" product market competition. Similarly, Oxman and Yildrim (2008) suggest that PE corporate governance practices spill over on competitors after a buyout. In contrast, Hsu, Reed, and Rocholl (2010) find that rivals experience a decrease in both their stock prices and their operating performance around the time of PE investments in their industry. These differences may arise because they use a different sample, focusing on transactions that are isolated in time and including private investments in public equity (PIPEs).

Our paper also relates to the subsequent work of Aldatmaz (2013), who address a similar question, using data from Burgiss Group (see Harris et al, 2014, for a description of this data set). The Burgiss data has the advantage of more complete information on the dollar value of equity investments made by private equity funds. The disadvantage compared to the data we use, however, is that the coverage of Burgiss is only part of the total PE universe, since it relies

\footnotetext{
${ }^{3}$ We have also ran tests for Granger-Sims causality, suggesting that past PE investment precedes subsequent improvements in industry performance, while past industry performance is unrelated to future PE investments. We are happy to share these results upon request.
} 
on LPs reporting to Burgiss. It also measures the equity value, while our estimates are of the total transaction value of deals, which is important given the leverage of these investments. Finally, Aldmataz (2013) has a different focus, as he considers the effect of PE investment on publicly traded companies in the same industry, while we consider the effect on the whole industry. This enables him to consider more countries, including developing ones, but will be less informative for countries where publicly traded companies only represent a small portion of the total industry. At any rate, the results of Aldatmaz (2013) are qualitatively very similar, and complementary, to ours.

In addition to our inability to completely put causality concerns to rest, as noted above, our analysis has some additional limitations. First, economic growth and volatility are only two of the issues that regulators consider when assessing the consequences of PE investments. Among the unaddressed topics are the impact on productivity, the distribution of wealth across society, and the competitive dynamics across industries. Second, our results suggest that spillovers from PE-backed companies may be important, but data limitations prevent us from exploring these dynamics in more detail here.

This paper proceeds as follows: Section 2 describes the construction of the dataset, and the results are presented in the Section 3. Section 4 presents concluding remarks.

\section{Data Sources and Sample Construction}

We combine two datasets in order to analyze how PE investments affect industries. One dataset contains information about PE investments compiled by Capital IQ, and another contains industry activity and performance across the Organisation for Economic Cooperation and Development (OECD) member countries that are included in the OECD's Structural Analysis 
Database (STAN).

\subsection{PE investment sample}

We use the Capital IQ (CIQ) database to construct a base sample of PE transactions. This database is recognized as the most comprehensive database of worldwide PE transactions. ${ }^{4}$ Strömberg (2008) compares CIQ LBO data during the 1980s with older LBO studies using 1980s data and estimates that during this early period, well before Capital IQ's formation, the database's coverage was somewhere between $70 \%$ and $85 \%$. The base sample contains all private placements and M\&A transactions in CIQ where (a) the list of acquirers includes (at least) one investment firm, (b) the transaction is classified as a "leveraged buyout," “management buyout," or "going private," (c) the deal was announced between January 1986 and December 2008, and (d) the target company is headquartered in an OECD country included in the STAN database. Thus, we only look at later-stage buyout transactions, and do not include venture capital investments. We exclude transactions that were announced but not completed as of December 2008, as well as transactions that did not involve a financial investor (e.g., a buyout executed by the management team itself was excluded). This results in a sample with about 14,300 transactions, involving 13,600 distinct firms.

We use various measures of PE activity relative to the size of the industry. For most of our analyses we use an indicator variable that equals one if there are any PE investments during any of the previous five years. This measure has the advantage of being well defined, even absent information about deal sizes and the total size of the industry. For some analyses, we use

\footnotetext{
${ }^{4}$ Most data services tracking PE investments were not established until the late 1990s. The most geographically comprehensive exception, SDC VentureXpert, focused primarily on capturing venture capital investments (rather than LBOs) until the mid-1990s.
} 
more refined measures of PE activity. One complication is that we only have information about the deal size for $50 \%$ of our transactions, so for those analyses we impute missing deal sizes by constructing fitted values from a regression of deal size on fixed effects for country, investment year, and target industry. We then generate aggregate country-year-industry measures of total PE volume in the form of summed deal sizes. ${ }^{5}$ We scale the total deal size calculated in this way by the total industry production as reported by STAN (see below) to construct a relative measure of PE investments in the industry and nation. To capture non-linearities in the relation between PE activity and output, and in order to reduce the noise in the aggregation, we construct quartile indicators for this normalized PE volume measure and use these variables as indicators of PE activity.

\subsection{Industry data}

The STAN database provides industry data across OECD countries compiled from national statistics offices. It contains economic information at the country, year, and industry level. Thus, a typical observation would be "the German transport equipment industry in 1999". STAN includes measures of total production, employment, and capital formation, as described in Table 1. Throughout this paper, we focus on the following measures of industry activity:

- Production (gross output), the value of goods and/or services produced in a year, whether sold or stocked, in current prices.

- Value added represents the industry's contribution to national GDP, i.e., output net of materials purchased. While the methodology for constructing this measure differs across nations, our focus here is on differences across time, which should reduce the effect of

\footnotetext{
${ }^{5}$ The results below are robust to the use of the data without the imputations.
} 
national differences in the measure.

- Labor costs, which comprise wages and salaries of employees paid by producers, as well as supplements such as contributions to social security, private pensions, health insurance, life insurance, and similar schemes.

- Number of employees, which is the traditional measure of employment, excluding selfemployed and unpaid family members working in the business.

- Gross capital formation is acquisitions, less disposals, of new tangible assets, as well as such intangible assets as mineral exploration and computer software. This variable is the closest aggregate to capital expenditures.

- Consumption of fixed capital measures: the reduction in the value of fixed assets used in production resulting from physical deterioration or normal obsolescence.

We are careful to collect the most recent data available at the STAN database.

Unfortunately, the STAN database is being updated slowly. As of January 2013, its coverage ends in 2009.

\subsection{Mapping Capital IQ to STAN industries}

We have to rely on the OECD/STAN industry classification, since the dependent variables are only defined at this level. The STAN database and Capital IQ, however, rely on different industry classifications. Industries in the STAN database are classified by the International Standard Industrial Classification (ISIC) Code, which does not map directly to the Capital IQ classification. To overcome this limitation, we first use the mapping from the CIQ industry classification into SIC Codes, and then use another existing mapping from SIC to ISIC industries. 
The mapping of CIQ industry classifications to SIC Codes includes only matches for the most detailed levels of the CIQ classifications to four-digit SIC Codes. Whenever possible we use this matching to get equivalent SIC Codes. PE transactions, however, are often defined by CIQ at a more aggregated industry level classification (hence includes multiple refined categories), for which no direct mapping to SIC, and ultimately to ISIC, exists.

In these cases, we used all SIC Codes that belong to the sub-categories of the industry classification of CIQ and therefore had multiple four-digit SIC Codes for a single CIQ (upper level) industry classification. In some cases, the mapping of a single aggregated level CIQ industry to multiple four-digit SIC Codes generated no conflict as all of the four-digit SICs corresponded to the same ISIC industry classification, creating a one-to-one mapping. In cases where the four-digit SIC Codes corresponded to different industries in the ISIC scheme, we matched each PE deal separately to its corresponding ISIC industry. In 390 transactions, we were not able to determine with certainty the appropriate match in the ISIC scheme, and those transactions were dropped, leaving us with roughly 14,000 PE transactions with ISIC classifications.

Finally, we group ISIC sub-industries, by using a more aggregated ISIC classification, to balance PE activity across industries. For example, there are $520 \mathrm{PE}$ transactions within the "food products and beverages" sub-industry classification, and only two transactions in the "tobacco" industry. The ISIC parent category of these two classifications is "food products, beverages, and tobacco." Therefore, we use this aggregate category rather than the two more refined ones. As a result, the industry classification we use is the detailed ISIC classification, but in cases of industries with very modest PE activity, we use the more aggregate industry level. In unreported analyses, we verify that the results hold using the detailed (non-grouped) industry 
classifications.

This results in a sample of 11,735 country-industry-year observations during the years 1986 to 2009. For each country-industry-year, we measure PE activity as the volume of PE deals occurring during the previous five years in this country and industry. In addition, we designate an observation a PE industry if it had at least one PE investment during those five years. These definitions were motivated by the holding periods reported by Strömberg (2008). ${ }^{6}$ With these definitions, we can only compare activity from 1991 to 2009, leaving us with 9,216 countryindustry-year observations.

Tables 2, 3, and 4 present the distribution of deals across industries, years, and countries. Several patterns are visible: (1) the heavy representation of buyouts as a share of economic activity in traditional industries, such as "textiles, textile products, leather," "machinery and equipment," "pulp, paper, paper products, printing," "electrical and optical equipment," and “chemical, rubber, plastics and fuel products"; (2) the acceleration in buyout activity, first modestly during the late 1980s and then especially in the mid-2000s; and (3) the greater level of activity in a handful of traditional hubs for PE funds, including the U.S., the Netherlands, Sweden, and the U.K. ${ }^{7}$

Although the concentration of PE activity across certain industries, years, and countries may have been a potential concern, our analysis includes industry-year, and country-industry fixed effects. This, together with the fact that country-industry-year is the unit of observation, ensures that our results are not driven by a few industry, year, or country outliers.

\footnotetext{
${ }^{6}$ The Capital IQ data contain the time of the PE fund's initial acquisition of a company but not the time of the subsequent sale. Funds tend to own these companies for 4.5-5 years, and our PE indicator is a proxy for whether any companies in a given country and industry are currently owned by PE funds.

${ }^{7}$ The level of transactions is high in Luxembourg, due to the tendency of many firms to domicile there for tax reasons, even though the bulk of their operations are elsewhere. As a result, we omit Luxembourg from the analyses below.
} 
One natural question is whether the volume of buyouts during our sample period is sufficiently large to have a material impact on the industries in which the funds invest. The most direct approach is to look at the implied share of PE investments in the industries in our sample. We wish to compute the mean share of total industry value represented by PE transactions annually.

Because enterprise value is not available for privately-held firms, we must approximate this measure. In particular, we compute a "revenue multiple" from the publicly traded firms in Global Compustat for each industry and year: the ratio between the aggregate enterprise value (the sum of the market value of equity, plus the book value of debt and preferred stock) of all publicly traded firms across all sample nations and the revenues for the same set of firms. ${ }^{8} \mathrm{We}$ then assume that this ratio also characterizes the privately-held firms in each industry in the same year. Thus, we estimate the ratio of the aggregate annual volume of PE investments in each industry and year (not using imputed deals, in order to be conservative) to the product of the estimated revenue multiple and the aggregate production by public and private firms, as estimated by the OECD. ${ }^{9}$

These ratios vary by year, reflecting the ebb and flow of PE activity. If we compute the average annual share of PE activity across the entire sample period in each industry, it varies from $0.9 \%$ (for transport equipment) to $13.5 \%$ (for machinery and equipment). The weighted average across all industries is $4.35 \%$, with an inter-quartile range from $2.5 \%$ to $7.1 \%$. This suggests that for the typical industry, the impact of PE over this period is quite substantial,

\footnotetext{
${ }^{8}$ Due to the small number of publicly traded firms, we are unable to compute a revenue multiple for the agriculture, hunting, forestry, and fishing industry category. While Global Compustat may not be comprehensive, we do not believe these omissions will introduce biases in the calculations of the multiples.

${ }^{9}$ It should be noted that the OECD constructs this measure to be as comparable as possible to the aggregate of the accounting measure of firm revenue.
} 
especially in light of the five-to-seven year holding period, which characterizes the typical PE investment (Strömberg 2008). This measure may understate the volume of PE activity. Not only are transactions with missing data excluded, but as discussed above, CIQ's coverage is incomplete.

Moreover, it is likely that having a significant fraction of firms in an industry under buyout ownership has a substantial effect on competitors as well. As discussed in the introduction, earlier work suggests that the impact of PE extends beyond the bought-out firms.

\section{Analysis}

\subsection{Industry performance}

We begin by examining the relationship between various industry characteristics and the role of PE in the industry. In each case, an observation is an industry-country-year triple, and the dependent variable is the growth rate of a given economic variable (e.g., employment).

Table 5 provides a univariate comparison of the growth of PE and non-PE industries. PE industries grow more quickly in terms of total production (output), value added, labor costs, and employment. However, the PE industries have lower growth rates of gross fixed capital formation and consumption of fixed capital. These basic comparisons do not control for industry, year, or country effects.

To control for these effects, we estimate several multivariate specifications. First, we include an indicator $\left(P E_{5}\right)$ that denotes whether the industry is a PE industry or not (defined, as noted above, as an industry with at least one PE investment during the previous five years). An advantage of this definition is that it only relies on the presence of PE deals, not on the aggregate 
value of these transactions. Second, we use indicators to capture whether an industry is a low or high PE industry (the omitted category is no PE). A low PE industry ( $\left.P E_{5} L o w\right)$ is a PE industry where the fraction of total imputed PE investments divided by total production (both normalized to 2008 U.S. dollars) is smaller than the median (conditional on having a non-zero level of PE investment), while a high PE industry $\left(\mathrm{PE}_{5} \mathrm{High}\right)$ has PE investments to production ratio above the median. ${ }^{10}$ We also perform the analysis dividing PE activity into quartiles to better measure the differential effects of different activity levels. For both the median and the quartile dummy specifications, industries with no PE activity are the omitted group. Hence, the coefficients can be interpreted relative to observations with zero PE investment in a given country-industry-year.

To control for common shocks across industries and countries, we include industry-year and country-industry fixed effects in our specifications. Hence, we estimate the fixed-effect panel regression:

$$
y_{c i y}=P E_{c i y} \beta+\eta_{c i}+\xi_{i y}+\varepsilon_{c i y}
$$

where $y_{c i y}$ is the endogeneous variable of interest, e.g., the growth rate of employment; ${ }^{11} P E_{c i y}$ is an indicator for whether the industry is a PE industry; $\eta_{c i}$ is a country-industry fixed effect; $\xi_{i y}$ is an industry-year fixed effect; and $\varepsilon_{c i y}$ is the residual error term.

The results in Table 6 indicate that industries with PE deals have significantly higher growth rates of production and value added. For total production, the coefficient of 0.863 implies that the total production of an average PE industry grows at an annual rate that is 0.836

\footnotetext{
${ }^{10}$ When defining the $P E_{5} L o w$ and $P E_{5}$ High indicators, we calculate the median of the amount of PE activity in each industry (aggregated over the previous five years and normalized by the industry's total production in constant 2008 USD) among the 3,637 industry-year observations with non-zero PE activity. This median value is 7.10. All our results are robust to normalizing by total employment instead of total production. Moreover, the results are robust to a softer definition of non-PE industries as industries with PE activity in the bottom 1\% of the distribution. ${ }^{11}$ We do not analyze more specific measures of total factor productivity (TFP), because TFP measures are only defined for manufacturing industries, and much of the variation in our data involves PE activity in other industries.
} 
percentage points higher than a non-PE industry. The average growth rate is $6.0 \%$, implying that PE ownership increases industry growth by approximately $15 \%$. For value added, we also find that the PE investments are associated with faster growth. In industries with lower levels of PE activity we find an average growth rate of $0.661 \%$ faster per year than industries without PE activity, and industries with more PE activity growing $1.157 \%$ faster on average.

In Table 6, we can also see that the effects of PE investments on total production and value added tend to increase in the amount of PE activity. However, the bottom row of the table reports the significance of a statistical test for differences between high- and low-PE industries, and only for value added is the increase statistically significant. Finally, we compare the differences between the four quartiles of PE activity. We find some evidence that the effect is stronger for industries with more PE activity, although the effect is slightly weaker in the top quartile of PE activity and the differences in the four coefficients are not statistically significant.

A natural concern is the direction of causality. It is possible that PE investors pick industries that have the potential to grow, and our results may reflect this industry choice rather than the causal effect of the investments on the industry. To mitigate this concern, we change our definition of the PE industry measure to only include investments during the period from two to five years prior to the observation, called the twice-lagged measure (the original PE measure included all five years prior to the observation). The results are reported in Table 7 . We find that the results are very similar, indicating that the effect that we find is unlikely to be driven by PE investors entering countries and industries where they expect stronger immediate growth.

Table 8 considers measures of employment. PE industries appear to grow significantly faster in terms of labor costs and the number of employees. The annual growth rate of total labor cost is 0.905 percentage points greater for PE industries, while the number of employees grows 
at an annual rate that is 0.777 percentage points greater.

These findings may be surprising, since a common concern is that PE investors act aggressively to reduce costs with little concern for employees. This concern is not necessarily inconsistent with our results, since we are looking at the industry rather than the firm level. Even if buyouts may lead to initial employment reductions at PE-backed firms (as found in Davis, et al. (2014) for the U.S.), the greater subsequent growth in total production, observed in Table 6, may lead to subsequent employment growth in the industry overall. ${ }^{12}$ Considering the specifications with PE activity quartiles, the growth rate of labor costs and number of employees may be fastest in industries with moderate levels of PE activity. This may suggest that the increase in growth is not entirely driven by increases at the PE-backed firms themselves but may also be driven by the spillover effects at other firms.

As above, we are concerned about the direction of causality. Table 9 repeats the analysis using the twice-lagged PE measure. The magnitudes in Tables 8 and 9 are largely similar, providing some evidence that suggests that the effects we identify are not mainly driven by PE investors picking industries with expectations of immediate employment growth.

Finally, in Table 10 we examine measures of fixed capital formation and consumption of fixed capital. The results are weaker than for the production and employment measures, with larger standard errors. If anything, the results suggest that PE investments increase the growth rate of gross fixed capital formation but do not affect consumption of fixed capital. These results, however, are more tentative. ${ }^{13}$

\footnotetext{
${ }^{12}$ Boucly, Sraer, and Thesmar (2011) document that PE investment leads to both higher employment growth and production growth in France.

${ }^{13}$ Using twice-lagged PE activity gives qualitatively similar results to those in Table 10.
} 


\subsection{Cyclical patterns}

We next analyze how PE relates to industry cycles. For each industry and year, we average the growth rate of the production and employment measures across countries to attain the average growth rate. This rate measures the annual aggregate shock in these variables (e.g., production output in the steel industry fell by $2 \%$ on average in 2002 across the nations in our sample). We then investigate whether PE industries are more or less exposed to this shock by including the PE measure interacted with this average growth measure in the regressions. In particular, we estimate the specification:

$$
y_{c i y}-\bar{y}_{i y}=P E_{c i y} \beta+\left(P E_{c i y} \times \bar{y}_{i y}\right) \gamma+\eta_{c i}+\xi_{i y}+\varepsilon_{c i y}
$$

where $y_{c i y}$ is the growth rate of interest (e.g., the growth rate of employment); $\bar{y}_{i y}$ is the mean of the growth rate (e.g., the average growth rate of employment in industry $i$ during year $y$ across all countries); ${ }^{14} P E_{c i y}$ is an indicator for whether the industry is a PE industry; $\eta_{c i}$ is a countryindustry fixed effect; $\xi_{i y}$ is an industry-year fixed effect; and $\varepsilon_{c i y}$ is the residual error term.

If $\mathrm{PE}$ and non-PE industries were equally sensitive to economic conditions, we would expect the coefficient on the interaction term, $\gamma$, to be zero. For example, if the average growth rate of employment first increases by $2 \%$ and this increase is equally large for PE and non-PE industries and then subsequently decreases by $2 \%$ and this decrease is also equally large for PE and non-PE industries, then $\gamma$ is zero. In contrast, imagine that the growth rate of employment increases by $2 \%$ on average, but this increase is distributed such that PE industries grow by $3 \%$ and non-PE industries grow by only $1 \%$, and this is followed by a $2 \%$ decline in growth rate, but this decline is distributed such that PE industries decline by $3 \%$ and non-PE industries decline by

\footnotetext{
${ }^{14}$ We calculate this average as an equal-weighted average. Since this average may be sensitive to outliers, we confirm that our results hold when the average is replace by the median.
} 
1\%. Then the coefficient $\gamma$ is positive and we interpret this as PE investments amplifying the exposure to the aggregate shocks.

In Tables 11 and 12, we examine the impact on production and employment. Across all the regressions, the interaction terms are either negative or insignificant, which suggests that PE industries, if anything, are less exposed to industry shocks than non-PE industries. To interpret the coefficients, using the estimates in the first regression in Table 12, if an industry on average experiences a 5\% increase in total labor costs in a given year (the aggregate shock), a PE industry will experience, on average, a $5.768 \%$ increase $(5 \%+1.498 \%+5 \%$ x $-0.146=$ $5.768 \%$ ). Conversely, following a 5\% decrease in labor costs, a PE industry will only experience a $-2.772 \%$ decline $(-5 \%+1.498 \%+(-5 \%) \times-0.146=-2.772 \%)$. Hence, an aggregate swing from $+5 \%$ to $-5 \%$ (a $10 \%$ difference) in growth rates translates into a swing from $5.768 \%$ to $-2.772 \%$ (a $8.54 \%$ difference) in the growth rates for PE industries.It may be the case, however, that the sensitivity to economic conditions is different in economic booms and busts. To explore such variations, we repeat the specification in Tables 11 and 12 with the addition that the variable $P E$ $x$ Avg. Growth is further interacted with a new variable Boom. The indicator Boom is defined to be one for the observations where the industry growth rate exceeds the average growth rate of this industry over the entire sample period and across all countries. ${ }^{15}$

We report the results in Table 13. In the specifications that include the new triple interaction (Specifications 2, 4, 6, and 8), the coefficients on PEx Avg. Growth are consistently negative, implying that during busts (non-boom observations), PE industries are consistently less exposed to these downturn than non-PE industries. Conversely, during Booms PE industries become more "risky" (note that the "risk exposure" during booms is the sum of the coefficients

\footnotetext{
${ }^{15}$ We get similar results when defining Booms as observations with growth rates that exceed the median, rather than the mean, which reduces the sensitivity to outliers
} 
for PExAvg Growth and PExAvg Growth x Boom). This greater "risk" during booms means that the growth rates of PE industries are now more exposed to the average (higher) industry growth rates.

Overall, it appears that PE activity translates into smaller employment fluctuations than average, but industries with a higher amount of PE activity may follow a growth pattern that is closer to that of the industry as a whole. It also appears that PE investments are particularly related to reduced downside risk of shocks to industry growth rates.

\subsection{Geographic patterns}

It is interesting to explore whether the impact of PE is different in Continental Europe than in the U.S. and U.K. Not only is the level of PE activity higher in the U.S. and U.K. than in most other nations, but the industry is also more established.

In unreported results, we repeat the base specifications reported in Tables 6 to 12 with the sample restricted to Continental European countries. All the main effects remain largely unchanged for the Continental Europe sample, suggesting that the effects are not primarily driven by the U.S. and U.K. Moreover, we find that that the effects are not statistically different for Continental Europe and the U.S./U.K., although the U.S./U.K. subsample is naturally a smaller sample, with reduced statistical power to distinguish the effect of PE investments.

\subsection{Causality}

While it appears that PE is associated with more rapid growth at an industry level in our sample, it is natural to wonder which way the causation runs. Does the presence of PE lead to higher production, or do PE investors invest where they anticipate industries will grow? Notably 
we cannot address this question in a definitive manner because there is little random variation associated with PE investments. Nevertheless, we provide some evidence that is consistent with the effects being driven by our preferred channel, rather than by reversed causality.

First, our baseline analysis considers PE investments during the five years prior to the observed growth in total production and employment. As discussed above, we also narrowed our measure to only include investments in the years two through five prior to the investment. If our effects were due to PE investors anticipating growth in particular sectors, they would have to be quite prescient to anticipate growth two years in advance.

Second, we address causality using an instrumental variables technique. As an instrument, we use the size of the private pension and insurance company asset pool in the nation and year, expressed as a percentage of GDP. This kind of identification strategy has been employed in other papers in the venture capital literature, such as Kortum and Lerner (2000) and Mollica and Zingales (2007).

To see the intuition behind this identification strategy, consider first the industry classified as "Basic Metals and Fabricated Metal Products." A regression of total production growth in this industry on the PE indicator gives a coefficient of 0.32 , showing that a PE investment in this industry is associated with $0.32 \%$ faster growth of total production in this industry. It is not possible to attribute this additional growth to PE investments, however, because PE investors may focus on this industry in periods of faster growth. To isolate the effect of the PE investments, note that periods with larger pension and insurance assets are also associated with more PE investments. Specifically, regressing the PE indicator for the industry on total institutional assets per GDP (in the same country and year) gives a coefficient of 0.80 . This regression is the first-stage regression, and the coefficient shows that, for example, a 10\% 
increase in institutional assets per capita is associated with an $8 \%$ increase in the probability of a PE investment in this industry. Changes in institutional assets, however, are largely determined by forces that are unrelated to the investment potential or growth of this particular industry, such as changing demographics or regulatory initiatives. The IV methodology then isolates the marginal increase in the growth of the production in this industry that arises from the increase in institutional assets. Estimating the second stage of the IV model gives a coefficient of 4.3. Taken at face value, this coefficient would suggest that the marginal increase in production growth that can be causally attributed to the PE investments is $4.3 \%$. However, when focusing on a single industry, the sample size is small with low statistical power. The coefficient is not statistically significant, and it has a $95 \%$ confidence interval from $-1.41 \%$ to $10.0 \%$.

The single-industry intuition still applies when including all industries in the analysis. ${ }^{16}$ Including all industries increases the sample size, and yields more precise estimates. In this analysis, we use two slightly different definitions of the instrument. In the simple specification, we assume that an increase in institutional assets has the same effect across all industries (the 0.80 coefficient above). Another, more flexible, specification allows the effect to vary across industries, because changes in institutional assets may not lead to exactly the same change in PE investments across industries. Formally, we obtain this flexibility by interacting the instrument with an industry indicator in the first stage. The empirical results remain largely unchanged. The exclusion restriction requires that changes in pension assets are independent of the error term in the regression. While this is difficult to establish empirically, pension funds

\footnotetext{
${ }^{16}$ Although the instrument only varies at the country-year level and PE investors invest at the country-year-industry level, the validity of the instrument follows from standard arguments. Formally, identification of the local average treatment effect (LATE) requires an exclusion restriction and a monotonicity condition (conditions 1 and 2 in Imbens and Angrist 1994). The monotonicity condition requires that an increase in institutional assets cannot be associated with a decrease in PE activity, which is reasonable.
} 
primarily change as a result of pension reforms, and we have reviewed changes in pension policies in Germany, Sweden, and the U.K. These reviews suggest that a wide array of considerations drive reforms in the rules governing long-term savings, including demographic pressures and the consequent dangers of running out of funding, the presence of perceived disparities (e.g., between white- and blue-collar workers, in the treatment of stay-at-home mothers), and the desire to increase the labor supply. We found no evidence that these changes are motivated by a perception that PE investments offered particularly attractive investment opportunities. One concern with respect to the exclusion restriction is that the motivation to increase the labor supply could potentially generate some of the results that we see. It is unlikely, however, that such reforms should be concentrated in industries where PE firms are more active.

To estimate this model, we supplement the dataset with data on financial assets held by domestic pension funds and insurance corporations from the OECD. ${ }^{17}$ We only include funded pension obligations, excluding for instance, public pension plans that hold very few investable assets but are funded on a "pay as you go" basis. Table 14 presents the distribution of financial assets across countries. The instruments for the PE variable we employ are financial assets relative to the country's GDP, along with country and industry fixed effects. Moreover, we also interact the instrument with industry indicators to permit institutional assets to have different effects on PE activity across different industries. The results are shown in Table 15, which also includes regular OLS estimates for comparison. ${ }^{18}$ The previous results of a positive impact of PE

\footnotetext{
${ }^{17}$ Financial assets are defined by the OECD as currency and deposits, securities other than shares such as bills and bonds, loans, equities, and other financial assets. We collect the data from the OECD's Annual Statistics on Institutional Investors database.

${ }^{18}$ In the first stage, the amount of pension assets has a large positive and significant (t-stat of 25.34) effect on the PE indicator. Additionally, we try various (unreported) alternative specifications of the first stage. We find that all these individual coefficients have large positive and significant effects (smallest t-stat across industries is 14.21). We estimate specifications with lagged pension assets relative to GDP (up to six years of lags). Across all alternative specifications, the results remain qualitatively unchanged.
} 
investment on industry performance remain robust. In most cases, the PE coefficient increases in magnitude. Interpreting this estimate as a local average treatment effect (LATE), this increase in the coefficient may suggest that local PE investors, who are more affected by the instrument, have a particularly large effect on growth rates.

\section{Conclusions}

The growth of the PE industry worldwide has spurred concerns about its potential impact on the global economy. This study looks across nations and industries to assess the impact of PE on industry performance.

The key results are, first, that industries where PE funds have invested in the past five years have grown more quickly. There are few significant differences between industries with low and high PE activity, suggesting that the results are at least partly driven by spillover effects from PE-backed firms to other firms in the industry. Second, we find no support for claims that economic activity in industries with PE backing is more exposed to aggregate shocks. Various robustness tests provide some evidence that is consistent with our preferred channel, rather than with reversed causality. Finally, these patterns are not driven solely by traditional PE hubs such as the U.K. and U.S., but also hold in Continental Europe.

This paper contributes to the overall literature on the economic impact of private equity. Much of the literature has focused on the Jensen (1989) hypothesis that PE-backed firms have improved operations, ignoring the question of how these investments impact the broader industry. ${ }^{19}$ One exception is Chevalier (1995a), who shows that in regions with supermarkets

\footnotetext{
${ }^{19}$ To highlight two recent works, Bloom, Sadun, and Van Reenen (2009) show that PE-backed firms are on average the best-managed group among the 4000 firms they survey. Davis, et al. (2014) compare all U.S.-based manufacturing establishments that received PE investments between 1980 and 2005 with similar establishments that
} 
receiving PE investments, the rivals responded by adding and expanding stores. This suggests that investments drive rivals not backed by PE to aggressively invest and leverage themselves.

There is also a related literature on market cycles. For instance, Axelson, et al. (2013) show that the level of leverage is driven by the cost of debt, rather than the industry- and firmspecific factors that affect leverage in publicly traded firms. The use of leverage is also strongly associated with higher valuation levels and lower PE fund returns, consistent with Kaplan and Stein (1993). If firms completing buyouts at market peaks employ excessive leverage, we may expect industries where a significant fraction of firms have undergone buyouts to experience more intense subsequent downturns, an expectation that is not supported here. ${ }^{20}$ In general, the relationship between active investment in an industry and its ongoing evolution has been little documented.

Our findings suggest a number of avenues for future research. First, it would be interesting to look at finer data on certain critical aspects of industry performance, such as the rates of layoffs, plant closings and openings, and product and process innovations. Second, it is important to understand the mechanisms by which the presence of PE-backed firms affects their peers. While Chevalier's (1995a, 1995b) study of the supermarket industry during the 1980s was an important first step, much more remains to be explored. Finally, we are limited by the available data, which ends in 2009. The buyout boom of the mid 2000s was so massive, and the subsequent crash in 2008 so dramatic, that the consequences may have been substantially different from other economic cycles (see Kosman, 2009). The full impact of the recent financial crisis is an important issue to explore in the future.

did not receive PE investments and show that PE-backed firms experience a substantial productivity growth advantage (about two percentage points) in the two years following the transaction

${ }^{20}$ This is consistent with Hotchkiss et al (2013), who find that PE-owned firms experience lower costs of financial distress than other distressed firms. 


\section{References}

Aldatmaz, S. (2013) Private Equity in the Global Economy: Evidence of Industry Spillovers. Working paper, University of North Carolina.

Arellano, M., and Bond, S. (1991) Some Tests of Specification for Panel Data: Monte Carlo Evidence and an Application to Employment Equations. In Review of Economic Studies 58, 277-297.

Axelson, U., Strömberg, P., Jenkinson, T., and Weisbach, M (2013) Borrow Cheap, Buy High? The Determinants of Leverage and Pricing in Buyouts. In Journal of Finance, 68(6), 2223-2267.

Baker, G.P. and K.H. Wruck (1989) Organizational Changes and Value Creation in Leveraged Buyouts: The Case of The O.M. Scott \& Sons Company. In Journal of Financial Economics 25, 163-190.

Bloom, N., Sadun, R. and Van Reenen, J. (2009) Do Private Equity-Owned Firms Have Better Management Practices? In Gurung, A. and Lerner, J. (eds.) Globalization of Alternative Investments Working Papers Volume 2: Global Economic Impact of Private Equity 2009, New York: World Economic Forum USA, 1-23. Available at http://www.weforum.org/pdf/cgi/pe/Full_Report2.pdf.

Blundell, R., and Bond, S. (1998) Initial Conditions and Moment Restrictions in Dynamic Panel Data Models. In Journal of Econometrics 87, 115-143.

Blomström, M., and Kokko, A., (1998) Multinational Corporations and Spillovers. In Journal of Economic Surveys 12, 247-277.

Chevalier, J. (1995a) Capital Structure and Product-Market Competition: Empirical Evidence from the Supermarket Industry. In American Economic Review 85 (June), 415-435.

Chevalier, J. (1995b) Do LBO Supermarkets Charge More? An Empirical Analysis of the Effects of LBOs on Supermarket Pricing. In Journal of Finance 50 (September), 1095-1112.

Davis, S., Haltiwanger, J., Jarmin, R., Lerner, J., and Miranda, J. (2014) Private Equity, Jobs and Productivity. In American Economic Review, forthcoming.

European Commission (2009) Commission Staff Working Document Accompanying the Proposal for a Directive of the European Parliament and of the Council on Alternative Investment Fund Managers and amending Directives 2004/39/EC and 2009/.../EC: Impact Assessment, COM(2009) 207/SEC (2009) 577. Brussels; European Commission.

Harris, R., Jenkinson, T., and Kaplan, S. (2014) Private Equity Performance: What Do We Know? Journal of Finance 64(5), 1851-1882.

Hochberg, Y., and Rauh, J. (2012). Local Overweighting and Underperformance: Evidence from Limited Partner Private Equity Investments. Review of financial studies, hhs128.

Honoré, B., and Kyriazidou, E. (2000) Panel Data Choice Models with Lagged Dependent Variables, Econometrica 68, 839-874. 
Hotchkiss, E., Smith, D., and Strömberg, P. (2013) Private Equity and the Resolution of Financial Distress. Unpublished Working Paper. Available at SSRN: http://papers.ssrn.com/sol3/papers.cfm?abstract_id=1787446.

Hsu, S., Reed, A. and Rocholl, J. (2010) Competitive Effects of Private Equity Investments. Unpublished Working Paper. Available at SSRN: http://ssrn.com/abstract=1571207.

Imbens, G., and Angrist, J. (1994) Identification and Estimation of Local Average Treatment Effects. In Econometrica 62, 467-475.

Jeng, L., and Wells, P. (2000) The Determinants of Venture Capital Funding: Evidence Across Countries. In Journal of Corporate Finance 6 (September), 241-289.

Jensen, M. (1986) Agency Costs of Free Cash Flow, Corporate Finance and Takeovers. In American Economic Review Papers and Proceedings 76 (May), 323-329.

Jensen, M. (1989) The Eclipse of the Public Corporation. In Harvard Business Review 67 (September/October), 61-74.

Kaplan, S. and Stein, J. (1993) The Evolution of Buyout Pricing and Financial Structure in the 1980s. In Quarterly Journal of Economics 108 (May), 313-357.

Kortum, S. and Lerner, J. (2000) Assessing the Contribution of Venture Capital to Innovation. In RAND Journal of Economics 31 (Winter), 674-692.

Kosman, J. (2009) The Buyout of America: How Private Equity Will Cause the Next Great Credit Crisis, New York: Penguin.

Luehrman, T.A. (2007) The Hertz Corporation (A). Harvard Business School Case 208-030.

Mollica, M. and Zingales, L. (2007) The Impact of Venture Capital on Innovation and the Creation of New Business. Unpublished Working Paper, University of Chicago.

Oxman, J. and Yildrim Y. (2008) Governance Effects of LBO Events. Unpublished Working Paper, Syracuse University.

Rasmussen, P. (2008) Taming the Private Equity Fund "Locusts." In Europe Today 8 (Spring), 130-133.

Service Employees International Union (2007) Behind the Buyouts: Inside the World of Private Equity. Washington, DC: SEIU.

Service Employees International Union (2008) Private Equity's Appetite for Infrastructure Could Put State and Local Taxpayers and Services at Risk. Draft policy discussion paper, SEIU.

Strömberg, P. (2008) The New Demography of Private Equity. In Gurung, A. and Lerner, J. (eds.) Globalization of Alternative Investments Working Papers Volume 1: Global Economic Impact of Private Equity 2008, New York: World Economic Forum USA, 326. Available at http://www.weforum.org/pdf/cgi/pe/Full_Report.pdf. 
Table 1: Descriptions of OECD STAN industry variables

Industry Variable Description

Production (gross output)

Value of goods and/or services produced in a year, whether sold or stocked, measured at current prices.

Value added

Industry contribution to national GDP. Value added comprises labor costs, consumption of fixed capital, taxes less subsidies, measured at current prices.

Wages and salaries of employees paid by producers,

Labor costs (compensation of employees) as well as supplements such as contributions to social security, private pensions, health insurance, life insurance and similar schemes.

Number of employees

Persons engaged in domestic production, excluding self-employed and unpaid family workers.

Acquisitions, less disposals, of new tangible assets (such as machinery and equipment, transport equipment, livestock, and construction) and new intangible assets (such as mineral exploration and computer software) to be used for more than one year, measured at current prices.

Reduction in the value of fixed assets used in production resulting from physical deterioration, normal obsolescence or normal accidental damage.

Source: OECD, STAN database, 2003. 
Table 2: Distribution of deals by industry. The sample consists of 9,216 country-industry-year observations of OECD countries between 1991 and 2009. Obs. shows the number of observations of the industry in the STAN data. PE Industries contains the number of observations classified as PE industries. An industry is a PE industry if it had at least one PE investment during the previous five years. Deals is the number of deals, and Deal Volume is the combined size of the deals (normalized to 2008 US\$ billions). Imputed Deal Volume imputes the size for deals with missing size information.

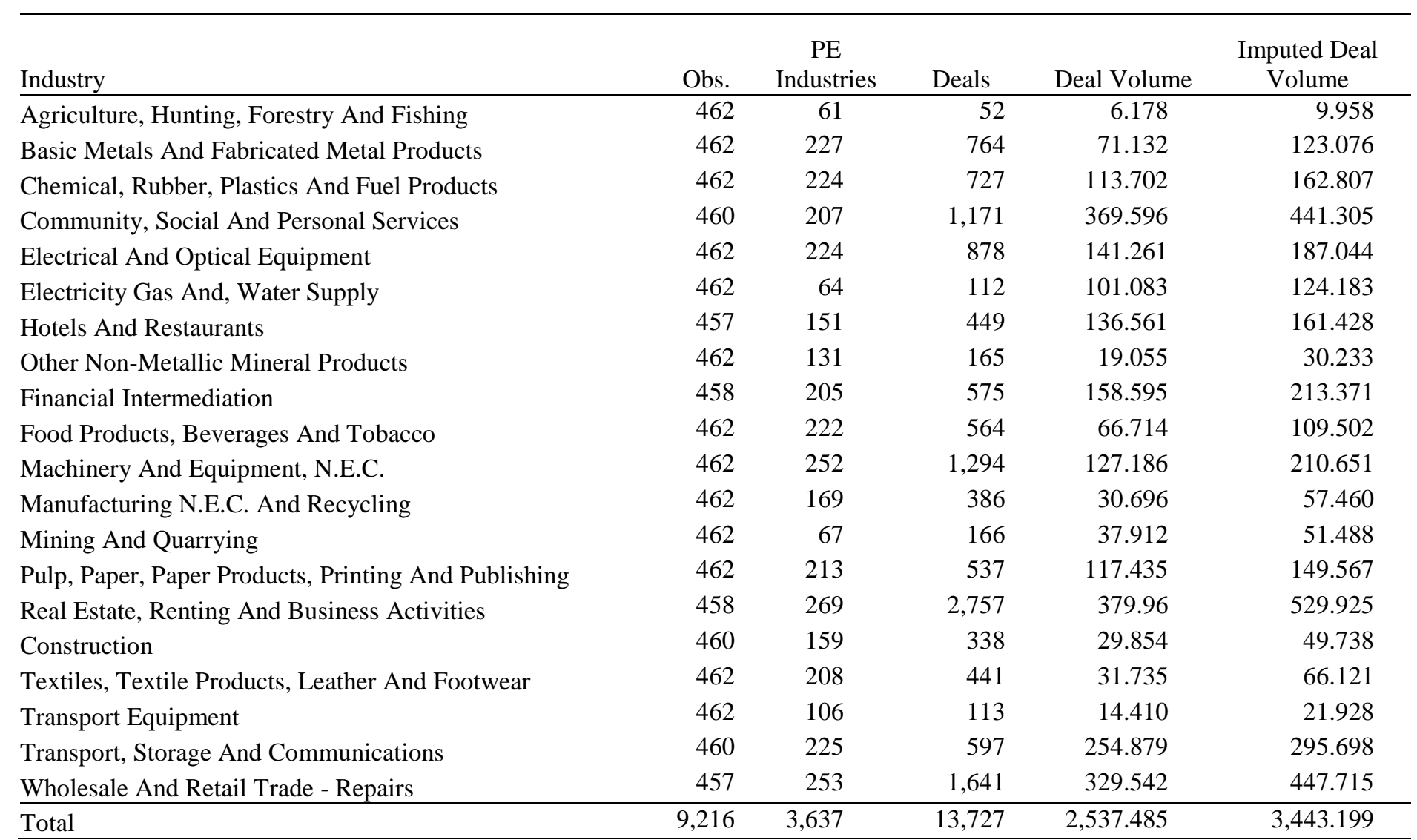


Table 3: Distribution of deals by year. The sample consists of 9,216 country-industry-year observations of OECD countries between 1991 and 2009. Obs. is the number of country-industry-year observations per year in the STAN data. PE Industries contains the number of observations classified as PE industries. An industry is a PE industry if it had at least one PE investment during the previous five years. Deals is the number of deals, and Deal Volume is the combined size of the deals (normalized to 2008 US\$ billions). Imputed Deal Volume imputes the deal size for deals with missing size information.

\begin{tabular}{|c|c|c|c|c|c|}
\hline Year & Observations & PE Industries & Deals & Deal Volume & $\begin{array}{c}\text { Imputed } \\
\text { Deal Volume }\end{array}$ \\
\hline 1986 & $\mathrm{n} / \mathrm{a}$ & $\mathrm{n} / \mathrm{a}$ & 95 & 19.562 & 27.204 \\
\hline 1987 & $\mathrm{n} / \mathrm{a}$ & $\mathrm{n} / \mathrm{a}$ & 111 & 18.509 & 28.127 \\
\hline 1988 & $\mathrm{n} / \mathrm{a}$ & $\mathrm{n} / \mathrm{a}$ & 160 & 42.947 & 61.781 \\
\hline 1989 & $\mathrm{n} / \mathrm{a}$ & $\mathrm{n} / \mathrm{a}$ & 142 & 60.453 & 68.956 \\
\hline 1990 & $\mathrm{n} / \mathrm{a}$ & $\mathrm{n} / \mathrm{a}$ & 124 & 21.696 & 33.550 \\
\hline 1991 & 436 & 65 & 158 & 13.292 & 21.881 \\
\hline 1992 & 449 & 75 & 178 & 15.730 & 26.803 \\
\hline 1993 & 493 & 82 & 196 & 16.440 & 29.411 \\
\hline 1994 & 500 & 89 & 260 & 15.442 & 25.525 \\
\hline 1995 & 500 & 104 & 346 & 34.985 & 49.796 \\
\hline 1996 & 500 & 131 & 430 & 43.525 & 57.243 \\
\hline 1997 & 500 & 147 & 653 & 55.407 & 86.002 \\
\hline 1998 & 500 & 183 & 867 & 94.417 & 144.103 \\
\hline 1999 & 500 & 203 & 819 & 86.124 & 130.694 \\
\hline 2000 & 500 & 219 & 775 & 103.704 & 136.950 \\
\hline 2001 & 500 & 239 & 670 & 79.220 & 100.670 \\
\hline 2002 & 500 & 255 & 713 & 92.750 & 121.481 \\
\hline 2003 & 500 & 261 & 932 & 144.741 & 177.671 \\
\hline 2004 & 500 & 276 & 1,201 & 201.257 & 275.450 \\
\hline 2005 & 500 & 276 & 1,405 & 257.562 & 366.256 \\
\hline 2006 & 500 & 299 & 1,765 & 398.772 & 545.134 \\
\hline 2007 & 480 & 295 & 1,840 & 757.902 & 975.565 \\
\hline 2008 & 480 & 251 & 519 & 126.214 & 172.564 \\
\hline 2009 & 378 & 187 & - & - & - \\
\hline Total & 9,216 & 3,637 & 14,359 & $2,700.652$ & $3,662.817$ \\
\hline
\end{tabular}


Table 4: Distribution of deals by country. The sample consists of 9,216 country-industry-year observations of OECD countries between 1991 and 2009. Observations is the number of observations in each country in the STAN data. PE Industries contains the number of observations classified as $P E$ industries. An industry is a PE industry if it had at least one PE investment during the previous five years. Deals is the number of deals, and Deal Volume is the combined size of the deals (normalized to 2008 US\$ billions). Imputed Deal Volume imputes the size for deals with missing size information.

\begin{tabular}{lccccc}
\hline Country & Observations & PE Industries & Deals & Deal Volume & Imputed Deal Volume \\
\hline Austria & 380 & 104 & 54 & 1.785 & 4.025 \\
Belgium & 380 & 156 & 120 & 13.826 & 23.486 \\
Canada & 360 & 199 & 303 & 101.473 & 120.966 \\
Switzerland & 360 & 134 & 118 & 17.664 & 33.277 \\
Czech Republic & 340 & 82 & 37 & 5.059 & 5.890 \\
Germany & 380 & 205 & 632 & 113.542 & 196.429 \\
Denmark & 380 & 126 & 152 & 10.096 & 18.257 \\
Spain & 380 & 179 & 267 & 42.786 & 48.166 \\
Finland & 380 & 194 & 203 & 7.698 & 16.633 \\
France & 360 & 280 & 1340 & 124.629 & 183.207 \\
United Kingdom & 360 & 318 & 2289 & 407.835 & 458.116 \\
Greece & 372 & 18 & 7 & 4.452 & 6.141 \\
Hungary & 380 & 59 & 22 & 6.678 & 9.374 \\
Ireland & 380 & 83 & 47 & 19.085 & 20.777 \\
Iceland & 380 & 9 & 5 & 0.270 & 0.280 \\
Italy & 380 & 246 & 350 & 44.293 & 60.524 \\
Japan & 378 & 92 & 80 & 24.820 & 31.461 \\
Korea & 380 & 58 & 21 & 6.393 & 6.393 \\
Netherlands & 380 & 238 & 330 & 87.937 & 130.141 \\
Norway & 380 & 105 & 81 & 5.612 & 10.806 \\
Poland & 326 & 88 & 61 & 2.696 & 3.378 \\
Portugal & 320 & 61 & 27 & 0.251 & 0.326 \\
Slovak Republic & 340 & 29 & 15 & 0.179 & 1.043 \\
Sweden & 380 & 201 & 277 & 44.298 & 59.677 \\
United States & 380 & 373 & 6,889 & $1,444.128$ & $1,994.426$ \\
\hline Total & 9,216 & 3,637 & 13,727 & $2,537.485$ & $3,443.199$ \\
\hline
\end{tabular}


Table 5: Industry growth variables. The sample consists of 9,216 country-industry-year observations of OECD countries between 1991 and 2009. An industry is considered as a PE industry if it had at least a single PE deal in the previous five years. $P$-value provides the p-value of a test of equality of the means of PE and non-PE industries. See Table 1 for variable definitions.

\begin{tabular}{|c|c|c|c|c|c|c|c|c|c|c|}
\hline & \multicolumn{3}{|c|}{ All Industries } & \multicolumn{3}{|c|}{ PE Industries } & \multicolumn{3}{|c|}{ Non-PE Industries } & \multirow[b]{2}{*}{$P$-value } \\
\hline & Observations & $\begin{array}{l}\text { Average } \\
\text { Growth }\end{array}$ & $\begin{array}{l}\text { Std. } \\
\text { Dev. }\end{array}$ & Observations & $\begin{array}{l}\text { Average } \\
\text { Growth }\end{array}$ & $\begin{array}{l}\text { Std. } \\
\text { Dev. }\end{array}$ & Observations & $\begin{array}{l}\text { Average } \\
\text { Growth }\end{array}$ & $\begin{array}{l}\text { Std. } \\
\text { Dev. }\end{array}$ & \\
\hline$\overline{\text { Production (gross output) }}$ & 8,144 & 6.0 & 9.5 & 3,624 & 6.2 & 9.3 & 4,520 & 5.7 & 9.8 & 0.01 \\
\hline Value added & 8,188 & 5.6 & 10.7 & 3,634 & 6.0 & 10.3 & 4,554 & 5.2 & 11.1 & 0.00 \\
\hline $\begin{array}{l}\text { Labor costs (compensation of } \\
\text { employees) }\end{array}$ & 7,888 & 5.4 & 8.1 & 3,477 & 5.9 & 8.1 & 4,411 & 4.8 & 8.1 & 0.00 \\
\hline Number of employees & 7,062 & -0.1 & 5.1 & 3,324 & 0.1 & 4.2 & 3,738 & -0.3 & 5.7 & 0.00 \\
\hline Gross fixed capital formation & 6,617 & 7.2 & 74.7 & 3,071 & 6.7 & 38.8 & 3,546 & 7.9 & 103.4 & 0.47 \\
\hline Consumption of fixed capital & 7,114 & 6.0 & 14.01 & 3,321 & 5.7 & 10.6 & 3,793 & 6.2 & 16.4 & 0.10 \\
\hline
\end{tabular}


Table 6: PE activity and growth rate of productivity. The table contains OLS panel regression coefficients. An observation is a countryindustry-year pair. The endogenous variable is the growth rate of production or value added (as defined by OECD). The exogenous variables are an indicator for positive PE activity over the previous five years at the country-industry level $\left(P E_{5}\right)$, indicators for whether the measured PE activity is below or above the median activity level $\left(P E_{5} L o w\right.$ and $\left.P E_{5} H i g h\right)$, and indicators for quartiles. The omitted base category is no PE activity over the previous five years. Country-industry $(C-I F E)$ and industry-year $(I-Y F E)$ fixed effects are included as indicated. Robust standard errors are in parentheses. $P E_{L}=P E_{H}$ contains the significance level of a Wald test of equality of the $P E$ Low and $P E$ High coefficients or all the quartile coefficients. Statistical significance at the $1 \%, 5 \%$, and $10 \%$ levels are indicated by $* * *, * *$, and *, respectively.

\begin{tabular}{|c|c|c|c|c|c|c|}
\hline & (1) & (2) & (3) & (4) & (5) & (6) \\
\hline & $\begin{array}{l}\text { Production } \\
\text { (gross } \\
\text { output) }\end{array}$ & $\begin{array}{l}\text { Production } \\
\text { (gross } \\
\text { output) }\end{array}$ & $\begin{array}{l}\text { Production } \\
\text { (gross } \\
\text { output) }\end{array}$ & Value Added & Value Added & Value Added \\
\hline $\mathrm{PE}_{5}$ & $\begin{array}{l}0.863 * * * \\
(0.231)\end{array}$ & & & $\begin{array}{l}0.881 * * * \\
(0.259)\end{array}$ & & \\
\hline $\mathrm{PE}_{5}$ Low & & $\begin{array}{l}0.790^{* * * *} \\
(0.255)\end{array}$ & & & $\begin{array}{l}0.661 * * \\
(0.275)\end{array}$ & \\
\hline $\mathrm{PE}_{5} \mathrm{High}$ & & $\begin{array}{l}0.955^{* * * *} \\
(0.273)\end{array}$ & & & $\begin{array}{l}1.157 * * * \\
(0.305)\end{array}$ & \\
\hline $\mathrm{PE}_{5} \mathrm{Q} 1$ & & & $\begin{array}{l}0.687 * * \\
(0.299)\end{array}$ & & & $\begin{array}{c}0.485 \\
(0.304)\end{array}$ \\
\hline $\mathrm{PE}_{5} \mathrm{Q} 2$ & & & $\begin{array}{l}0.918 * * * \\
(0.289)\end{array}$ & & & $\begin{array}{l}0.838 * * \\
(0.333)\end{array}$ \\
\hline $\mathrm{PE}_{5} \mathrm{Q} 3$ & & & $\begin{array}{l}1.181 * * * \\
(0.305)\end{array}$ & & & $\begin{array}{l}1.273 * * * \\
(0.354)\end{array}$ \\
\hline $\mathrm{PE}_{5} \mathrm{Q}_{4}$ & & & $\begin{array}{l}0.724 * * \\
(0.306)\end{array}$ & & & $\begin{array}{l}1.067 * * * \\
(0.326)\end{array}$ \\
\hline C-I FE & Yes & Yes & Yes & Yes & Yes & Yes \\
\hline I-Y FE & Yes & Yes & Yes & Yes & Yes & Yes \\
\hline$\overline{P E_{L}}=\mathrm{PE}_{\mathrm{H}}$ & & 0.519 & 0.292 & & $0.060 * *$ & 0.165 \\
\hline Observations & 8,134 & 8,134 & 8,134 & 8,173 & 8,173 & 8,173 \\
\hline
\end{tabular}


Table 7: Twice-lagged PE activity and growth rate of productivity. The table contains OLS panel regression coefficients. An observation is a country-industry-year pair. The endogenous variable is the growth rate of production or value added (as defined by OECD). The exogenous variables are an indicator for positive PE activity over the previous four years -2 to -5 , i.e., not including the year prior to the year where the growth in the endogenous variable is measured $\left(P E_{2-5}\right)$, indicators for whether the measured PE activity is below or above the median activity level $\left(P E_{2-5}\right.$ Low and $P E_{2-5} \mathrm{High}$ ), and indicators for quartiles. The omitted base category is no PE activity over the previous five years. Country-industry $(C-I F E)$ and industry-year $(I-Y F E)$ fixed effects are included as indicated. Robust standard errors are in parentheses. $P E_{L}=P E_{H}$ contains the significance level of a Wald test of equality of the $P E$ Low and $P E$ High coefficients or all the quartile coefficients. Statistical significance at the $1 \%, 5 \%$, and $10 \%$ levels are indicated by $* * *, * *$, and $*$, respectively.

\begin{tabular}{|c|c|c|c|c|c|c|}
\hline & (1) & (2) & (3) & (4) & (5) & (6) \\
\hline & $\begin{array}{l}\text { Production } \\
\text { (gross } \\
\text { output) }\end{array}$ & $\begin{array}{l}\text { Production } \\
\text { (gross } \\
\text { output) }\end{array}$ & $\begin{array}{l}\text { Production } \\
\text { (gross } \\
\text { output) }\end{array}$ & Value Added & Value Added & Value Added \\
\hline$\overline{\mathrm{PE}_{2-5}}$ & $\begin{array}{l}0.863^{* * *} \\
(0.231)\end{array}$ & & & $\begin{array}{l}0.881 * * * \\
(0.259)\end{array}$ & & \\
\hline $\mathrm{PE}_{2-5}$ Low & & $\begin{array}{l}0.721 * * * \\
(0.232)\end{array}$ & & & $\begin{array}{l}0.662 * * \\
(0.266)\end{array}$ & \\
\hline $\mathrm{PE}_{2-5}$ High & & $\begin{array}{l}0.786^{* * * *} \\
(0.265)\end{array}$ & & & $\begin{array}{l}1.143^{* * *} \\
(0.306)\end{array}$ & \\
\hline $\mathrm{PE}_{2-5} \mathrm{Q} 1$ & & & $\begin{array}{l}0.827 * * * \\
(0.272)\end{array}$ & & & $\begin{array}{c}0.586^{* *} \\
(0.292)\end{array}$ \\
\hline $\mathrm{PE}_{2-5} \mathrm{Q} 2$ & & & $\begin{array}{c}0.652 * * \\
(0.292)\end{array}$ & & & $\begin{array}{c}0.751^{* *} \\
(0.334)\end{array}$ \\
\hline $\mathrm{PE}_{2-5} \mathrm{Q} 3$ & & & $\begin{array}{l}1.072^{* * * *} \\
(0.297)\end{array}$ & & & $\begin{array}{l}1.314 * * * \\
(0.346)\end{array}$ \\
\hline $\mathrm{PE}_{2-5} \mathrm{Q} 4$ & & & $\begin{array}{c}0.437 \\
(0.300)\end{array}$ & & & $\begin{array}{l}0.970 * * * \\
(0.355)\end{array}$ \\
\hline C-I FE & Yes & Yes & Yes & Yes & Yes & Yes \\
\hline I-Y FE & Yes & Yes & Yes & Yes & Yes & Yes \\
\hline$\overline{P E_{L}}=\mathrm{PE}_{\mathrm{H}}$ & & 0.794 & $0.099 *$ & & $0.098 *$ & 0.247 \\
\hline Observations & 8,134 & 8,134 & 8,134 & 8,173 & 8,173 & 8,173 \\
\hline
\end{tabular}


Table 8: PE activity and growth rate of employment. The table contains OLS panel regression coefficients. An observation is a countryindustry-year pair. The endogenous variable is the annual growth rate of labor costs or total employment (as defined by OECD). The exogenous variables are an indicator for positive PE activity over the previous five years at the country-industry level $\left(P E_{5}\right)$, indicators for whether the measured PE activity is below or above the median activity level ( $P E_{5}$ Low and $\left.P E_{5} H i g h\right)$, and indicators for quartiles. The omitted base category is no PE activity over the previous five years. Country-industry $(C-I F E)$ and industry-year $(I-Y F E)$ fixed effects are included as indicated. Robust standard errors are in parentheses. $P E_{L}=P E_{H}$ contains the significance level of a Wald test of equality of the PE Low and $P E$ High coefficients or all the quartile coefficients. Statistical significance at the $1 \%, 5 \%$, and $10 \%$ levels are indicated by ***,**, and *, respectively.

\begin{tabular}{|c|c|c|c|c|c|c|}
\hline & (1) & (2) & (3) & (4) & (5) & (6) \\
\hline & $\begin{array}{l}\text { Labor Costs } \\
\text { (compensation } \\
\text { of emplovees) }\end{array}$ & $\begin{array}{l}\text { Labor Costs } \\
\text { (compensation } \\
\text { of emplovees) }\end{array}$ & $\begin{array}{l}\text { Labor Costs } \\
\text { (compensation } \\
\text { of emplovees) }\end{array}$ & $\begin{array}{l}\text { Number of } \\
\text { Employees }\end{array}$ & $\begin{array}{l}\text { Number of } \\
\text { Employees }\end{array}$ & $\begin{array}{l}\text { Number of } \\
\text { Employees }\end{array}$ \\
\hline$\overline{\mathrm{PE}_{5}}$ & $\begin{array}{l}0.905^{* * *} \\
(0.198)\end{array}$ & & & $\begin{array}{l}0.777 * * * \\
(0.147)\end{array}$ & & \\
\hline $\mathrm{PE}_{5}$ Low & & $\begin{array}{l}0.642^{* * *} \\
(0.214)\end{array}$ & & & $\begin{array}{l}0.922 * * * \\
(0.169)\end{array}$ & \\
\hline $\mathrm{PE}_{5}$ High & & $\begin{array}{l}1.239 * * * \\
(0.229)\end{array}$ & & & $\begin{array}{l}0.598 * * * \\
(0.171)\end{array}$ & \\
\hline $\mathrm{PE}_{5} \mathrm{Q} 1$ & & & $\begin{array}{c}0.165 \\
(0.252)\end{array}$ & & & $\begin{array}{l}0.820 * * * \\
(0.218)\end{array}$ \\
\hline $\mathrm{PE}_{5} \mathrm{Q} 2$ & & & $\begin{array}{l}1.123^{* * * *} \\
(0.243)\end{array}$ & & & $\begin{array}{l}1.056^{* * *} \\
(0.183)\end{array}$ \\
\hline $\mathrm{PE}_{5} \mathrm{Q} 3$ & & & $\begin{array}{l}1.439^{* * *} \\
(0.273)\end{array}$ & & & $\begin{array}{l}0.867^{* * * *} \\
(0.189)\end{array}$ \\
\hline $\mathrm{PE}_{5} \mathrm{Q} 4$ & & & $\begin{array}{l}1.131^{* * * *} \\
(0.241)\end{array}$ & & & $\begin{array}{c}0.319 \\
(0.197)\end{array}$ \\
\hline C-I FE & Yes & Yes & Yes & Yes & Yes & Yes \\
\hline I-Y FE & Yes & Yes & Yes & Yes & Yes & Yes \\
\hline $\mathrm{PE}_{\mathrm{L}}=\mathrm{PE}_{\mathrm{H}}$ & & $0.004 * * *$ & $0.000 * * *$ & & $0.057 *$ & $0.002 * * *$ \\
\hline Observations & 7,885 & 7,885 & 7,885 & 7,928 & 7,928 & 7,928 \\
\hline
\end{tabular}


Table 9: Twice-lagged PE activity and growth rate of employment. The table contains OLS panel regression coefficients. An observation is a country-industry-year pair. The endogenous variable is the annual growth rate of labor costs or total employment (as defined by OECD). The exogenous variables are an indicator for positive PE activity over the previous four years -2 to -5 , i.e., not including the year previous to the year where the growth in the endogenous variable is measured $\left(P E_{2-5}\right)$, indicators for whether the measured PE activity is below or above the median activity level $\left(P E_{2-5}\right.$ Low and $\left.P E_{2-5} \mathrm{High}\right)$, and indicators for quartiles. The omitted base category is no PE activity over the previous five years.

Country-industry $(C-I F E)$ and industry-year $(I-Y F E)$ fixed effects are included as indicated. Robust standard errors are in parentheses. $P E_{L}=P E_{H}$ contains the significance level of a Wald test of equality of the PE Low and PE High coefficients or all the quartile coefficients. Statistical significance at the $1 \%, 5 \%$, and $10 \%$ levels are indicated by $* * *, * *$, and $*$, respectively.

\begin{tabular}{|c|c|c|c|c|c|c|}
\hline & (1) & (2) & (3) & (4) & (5) & (6) \\
\hline & $\begin{array}{l}\text { Labor Costs } \\
\text { (compensation } \\
\text { of emplovees) }\end{array}$ & $\begin{array}{l}\text { Labor Costs } \\
\text { (compensation } \\
\text { of emplovees) }\end{array}$ & $\begin{array}{l}\text { Labor Costs } \\
\text { (compensation } \\
\text { of emplovees) }\end{array}$ & $\begin{array}{l}\text { Number of } \\
\text { Employees }\end{array}$ & $\begin{array}{l}\text { Number of } \\
\text { Employees }\end{array}$ & $\begin{array}{l}\text { Number of } \\
\text { Employees }\end{array}$ \\
\hline$\overline{\mathrm{PE}_{2-5}}$ & $\begin{array}{l}0.905^{* * *} \\
(0.198)\end{array}$ & & & $\begin{array}{l}0.777 \text { *** } \\
(0.147)\end{array}$ & & \\
\hline $\mathrm{PE}_{2-5}$ Low & & $\begin{array}{l}0.614 * * * \\
(0.199)\end{array}$ & & & $\begin{array}{l}0.829 * * * \\
(0.159)\end{array}$ & \\
\hline $\mathrm{PE}_{2-5} \mathrm{High}$ & & $\begin{array}{l}1.242^{* * *} \\
(0.212)\end{array}$ & & & $\begin{array}{l}0.658 * * * \\
(0.160)\end{array}$ & \\
\hline $\mathrm{PE}_{2-5} \mathrm{Q} 1$ & & & $\begin{array}{c}0.214 \\
(0.230)\end{array}$ & & & $\begin{array}{l}0.762^{* * * *} \\
(0.204)\end{array}$ \\
\hline $\mathrm{PE}_{2-5} \mathrm{Q} 2$ & & & $\begin{array}{l}1.017 * * * \\
(0.234)\end{array}$ & & & $\begin{array}{l}0.930^{* * * *} \\
(0.175)\end{array}$ \\
\hline $\mathrm{PE}_{2-5} \mathrm{Q} 3$ & & & $\begin{array}{l}1.417^{* * * *} \\
(0.254)\end{array}$ & & & $\begin{array}{l}1.008^{* * * *} \\
(0.169)\end{array}$ \\
\hline $\mathrm{PE}_{2-5} \mathrm{Q} 4$ & & & $\begin{array}{l}1.158^{* * *} \\
(0.239)\end{array}$ & & & $\begin{array}{c}0.285 \\
(0.199)\end{array}$ \\
\hline C-I FE & Yes & Yes & Yes & Yes & Yes & Yes \\
\hline I-Y FE & Yes & Yes & Yes & Yes & Yes & Yes \\
\hline$\overline{\mathrm{PE}_{\mathrm{L}}}=\mathrm{PE}_{\mathrm{H}}$ & & $0.001 * * *$ & $0.000 * * *$ & & 0.288 & $0.000 * * *$ \\
\hline Observations & 7,885 & 7,885 & 7,885 & 7,928 & 7,928 & 7,928 \\
\hline
\end{tabular}


Table 10: PE activity and growth rate of capital formation. The table contains OLS panel regression coefficients. An observation is a countryindustry-year pair. The endogenous variable is the annual growth rate of gross fixed capital formation or consumption of fixed capital (as defined by OECD). The exogenous variables are an indicator for positive PE activity over the previous five years at the country-industry level $\left(P E_{5}\right)$, indicators for whether the measured PE activity is below or above the median activity level $\left(P E_{5} L O w\right.$ and $P E_{5}$ High), and indicators for quartiles. The omitted base category is no PE activity over the previous five years. Country-industry $(C-I F E)$ and industry-year $(I-Y F E)$ fixed effects are included as indicated. Robust standard errors are in parentheses. $P E_{L}=P E_{H}$ contains the significance level of a Wald test of equality of the $P E$ Low and PE High coefficients or all the quartile coefficients. Statistical significance at the $1 \%, 5 \%$, and $10 \%$ levels are indicated by $* * *, * *$, and $*$, respectively.

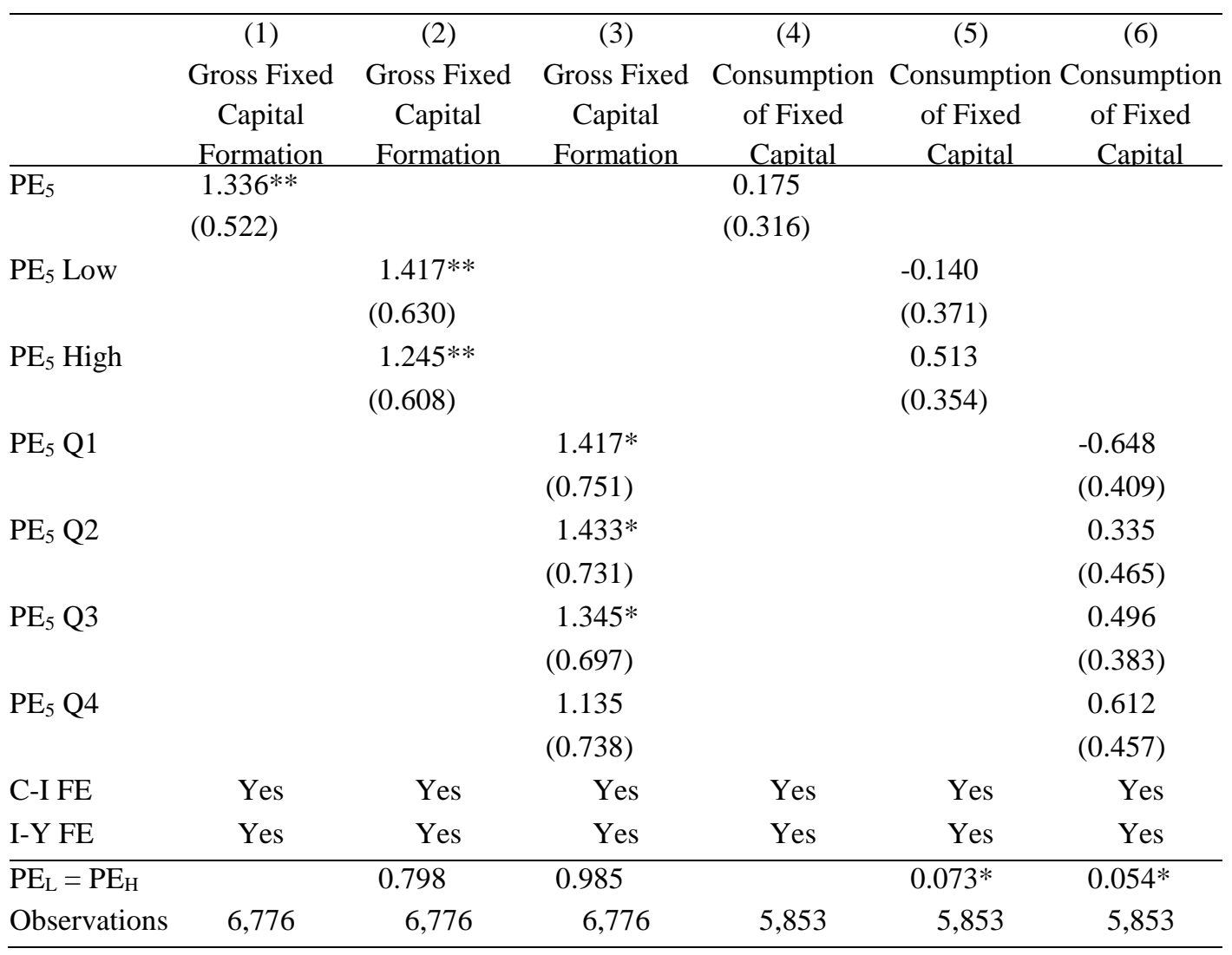


Table 11: PE activity and productivity cycles. The table contains OLS panel regression coefficients. An observation is the annual growth rate of the indicated productivity measure (subtracting its average growth rate across countries) at the country-industry-year level. The exogenous variable $P E_{5} \times A v g$ growth contains the interaction between $P E_{5}$ and the average growth rate of the endogenous variable, averaged over countries. $P E_{5}$ is an indicator for positive PE activity in the country-industry during the previous five years. The variables $P E_{5} L o w$ $x A v g$ growth and $P E_{5}$ High $x$ Avg growth are constructed similarly, where $P E_{5} L o w$ and $P E_{5}$ High are indicators for below or above median PE activity. Standard errors in parentheses are robust. Statistical significance at the $1 \%, 5 \%$, and $10 \%$ levels are indicated by $* * *, * *$, and $*$, respectively.

\begin{tabular}{|c|c|c|c|c|}
\hline & (1) & (2) & (3) & (4) \\
\hline & $\begin{array}{l}\text { Production } \\
\text { (gross } \\
\text { output) }\end{array}$ & $\begin{array}{l}\text { Production } \\
\text { (gross } \\
\text { output) }\end{array}$ & $\begin{array}{l}\text { Value } \\
\text { Added }\end{array}$ & $\begin{array}{l}\text { Value } \\
\text { Added }\end{array}$ \\
\hline $\mathrm{PE}_{5} \mathrm{x}$ Avg growth & $\begin{array}{c}0.013 \\
(0.029)\end{array}$ & & $\begin{array}{l}-0.033 \\
(0.040)\end{array}$ & \\
\hline $\mathrm{PE}_{5}$ Low $\mathrm{x}$ Avg growth & & $\begin{array}{l}-0.046 \\
(0.038)\end{array}$ & & $\begin{array}{l}-0.125^{* *} \\
(0.053)\end{array}$ \\
\hline $\mathrm{PE}_{5}$ High $\mathrm{x}$ Avg growth & & $\begin{array}{c}0.055 \\
(0.037)\end{array}$ & & $\begin{array}{c}0.047 \\
(0.053)\end{array}$ \\
\hline $\mathrm{PE}_{5}$ & $\begin{array}{l}0.802 * * * \\
(0.273)\end{array}$ & & $\begin{array}{l}1.013 * * * \\
(0.306)\end{array}$ & \\
\hline $\mathrm{PE}_{5}$ Low & & $\begin{array}{l}1.075 * * * \\
(0.316)\end{array}$ & & $\begin{array}{l}1.334 * * * \\
(0.363)\end{array}$ \\
\hline $\mathrm{PE}_{5} \mathrm{High}$ & & $\begin{array}{l}0.702 * * \\
(0.325)\end{array}$ & & $\begin{array}{l}0.919 * * \\
(0.367)\end{array}$ \\
\hline C-I FE & Yes & Yes & Yes & Yes \\
\hline I-Y FE & Yes & Yes & Yes & Yes \\
\hline$\overline{\text { Observations }}$ & 8,134 & 8,134 & 8,173 & 8,173 \\
\hline
\end{tabular}


Table 12: PE activity and employment cycles. The table contains OLS panel regression coefficients. An observation is the annual growth rate of the indicated employment measure (subtracting its average growth rate across countries) at the country-industry-year level. The exogenous variable $P E_{5} \times A v g$ growth contains the interaction between $P E$ and the average growth rate of the endogenous variable, averaged over countries. $P E_{5}$ is an indicator for positive $P E$ activity in the country-industry during the previous five years. The variables $P E_{5}$ Low $x$ Avg growth and $P E_{5} H i g h \times A v g$ growth are constructed similarly, where $P E_{5} L O w$ and $P E_{5} H i g h$ are indicators for below or above median PE activity. The regressions contain country-industry $(C-I F E)$ fixed effects. Standard errors in parentheses are robust. Statistical significance at the $1 \%, 5 \%$, and $10 \%$ levels are indicated by $* * *, * *$, and $*$, respectively.

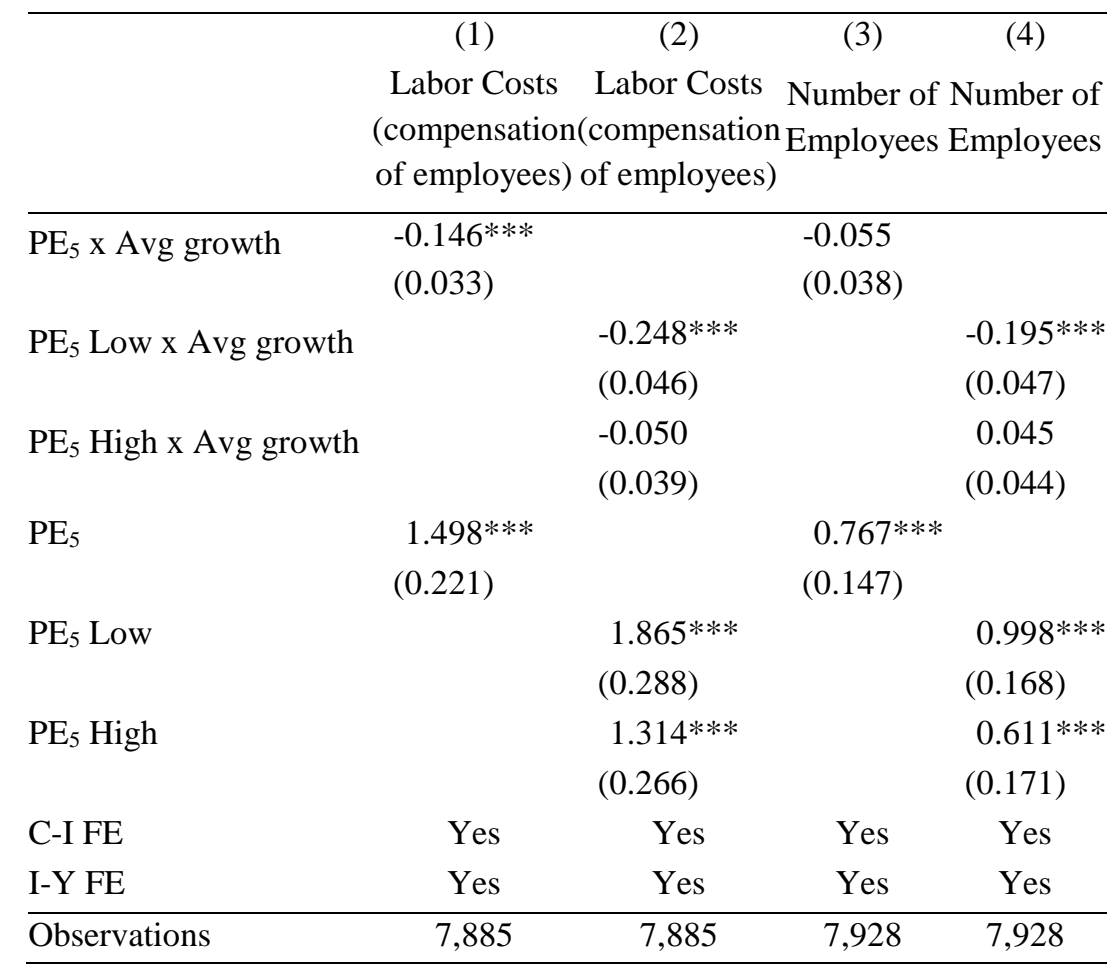


Table 13: PE activity and economic booms and busts. The table contains OLS panel regression coefficients. An observation is the annual growth rate of the indicated employment measure (subtracting its average growth rate across countries) at the country-industry-year level. The exogenous variable $P E_{5} \times A v g$ growth contains the interaction between $P E$ and the average growth rate of the endogenous variable, averaged over countries. $P E_{5}$ is an indicator for positive PE activity in the country-industry during the previous five years. The indicator Boom is defined to be one for the observations where the industry growth rate exceeds the average growth rate of this industry over the entire sample period and across all countries. The regressions contain country-industry $(C-I F E)$ fixed effects. Standard errors in parentheses are robust. Statistical significance at the $1 \%, 5 \%$, and $10 \%$ levels are indicated by $* * *, * *$, and $*$, respectively.

\begin{tabular}{|c|c|c|c|c|c|c|c|c|}
\hline & $\begin{array}{c}1 \\
\text { Production }\end{array}$ & $\begin{array}{c}2 \\
\text { Production }\end{array}$ & $\begin{array}{c}3 \\
\text { Value Added }\end{array}$ & $\begin{array}{c}4 \\
\text { Value Added }\end{array}$ & $\begin{array}{c}5 \\
\text { Labor Costs }\end{array}$ & $\begin{array}{c}6 \\
\text { Labor Costs }\end{array}$ & $\begin{array}{c}7 \\
\text { Employees }\end{array}$ & $\begin{array}{c}8 \\
\text { Employees }\end{array}$ \\
\hline $\mathrm{PE}_{5}$ & $\begin{array}{l}0.802 * * * \\
(0.273)\end{array}$ & $\begin{array}{c}0.440 \\
(0.283)\end{array}$ & $\begin{array}{l}1.013^{* * *} \\
(0.306)\end{array}$ & $\begin{array}{c}0.587^{*} \\
(0.323)\end{array}$ & $\begin{array}{l}1.498 * * * \\
(0.221)\end{array}$ & $\begin{array}{l}1.405 * * * \\
(0.225)\end{array}$ & $\begin{array}{l}0.766 * * * \\
(0.147)\end{array}$ & $\begin{array}{l}0.781 * * * \\
(0.149)\end{array}$ \\
\hline $\mathrm{PE}_{5} \mathrm{x}$ Avg Growth & $\begin{array}{c}0.013 \\
(0.029)\end{array}$ & $\begin{array}{l}-0.238 * * * \\
(0.033)\end{array}$ & $\begin{array}{l}-0.033 \\
(0.040)\end{array}$ & $\begin{array}{l}-0.403 * * * \\
(0.047)\end{array}$ & $\begin{array}{l}-0.146^{* * * *} \\
(0.033)\end{array}$ & $\begin{array}{l}-0.462 * * * \\
(0.034)\end{array}$ & $\begin{array}{l}-0.055^{*} \\
(0.038)\end{array}$ & $\begin{array}{l}-0.036 \\
(0.048)\end{array}$ \\
\hline $\mathrm{PE}_{5} \times$ Avg Growth x Boom & & $\begin{array}{l}0.450 * * * \\
(0.031)\end{array}$ & & $\begin{array}{l}0.727 * * * \\
(0.043)\end{array}$ & & $\begin{array}{l}0.584 * * * \\
(0.030)\end{array}$ & & $\begin{array}{l}-0.050 \\
(0.077)\end{array}$ \\
\hline C-I FE & Yes & Yes & Yes & Yes & Yes & Yes & Yes & Yes \\
\hline I-Y FE & Yes & Yes & Yes & Yes & Yes & Yes & Yes & Yes \\
\hline Obs. & 8,134 & 8,134 & 8,173 & 8,173 & 7,885 & 7,885 & 7,928 & 7,928 \\
\hline
\end{tabular}


Table 14: Distribution of financial assets by country. Observations is the number of country-year pairs for which financial assets data is available (since 1991). Financial Assets is the value of assets held by domestic autonomous pension funds and insurance corporations (in 2008 US\$ billions). Financial Assets to GDP Ratio is the fraction of financial assets normalized by country's GDP.

\begin{tabular}{|c|c|c|c|c|c|}
\hline \multirow[b]{2}{*}{ Country } & \multirow[b]{2}{*}{ Observations } & \multicolumn{2}{|c|}{$\begin{array}{l}\text { Financial Assets } \\
\text { (2008 US\$ billions) }\end{array}$} & \multicolumn{2}{|c|}{$\begin{array}{l}\text { Financial Assets to } \\
\text { GDP Ratio }\end{array}$} \\
\hline & & Average & Std. Dev. & Average & Std. Dev. \\
\hline Austria & 19 & 94.37 & 38.06 & 0.29 & 0.08 \\
\hline Belgium & 19 & 176.48 & 102.62 & 0.44 & 0.20 \\
\hline Canada & 19 & 862.78 & 301.50 & 0.82 & 0.11 \\
\hline Czech Republic & 15 & 15.55 & 10.98 & 0.11 & 0.04 \\
\hline Denmark & 16 & 282.99 & 94.71 & 1.05 & 0.19 \\
\hline Finland & 15 & 48.33 & 16.61 & 0.23 & 0.05 \\
\hline France & 16 & 1573.83 & 647.00 & 0.69 & 0.19 \\
\hline Germany & 19 & 1573.28 & 499.81 & 0.51 & 0.13 \\
\hline Greece & 15 & 11.85 & 5.59 & 0.05 & 0.01 \\
\hline Hungary & 19 & 11.17 & 11.50 & 0.10 & 0.07 \\
\hline Iceland & 9 & 18.27 & 7.16 & 1.16 & 0.23 \\
\hline Ireland & 9 & 277.84 & 101.77 & 1.23 & 0.26 \\
\hline Italy & 15 & 511.53 & 250.04 & 0.27 & 0.10 \\
\hline Japan & 19 & 3557.39 & 687.20 & 0.65 & 0.17 \\
\hline Korea & 8 & 374.25 & 76.55 & 0.43 & 0.05 \\
\hline Netherlands & 19 & 971.67 & 333.89 & 1.53 & 0.25 \\
\hline Norway & 15 & 111.17 & 38.82 & 0.38 & 0.03 \\
\hline Poland & 18 & 34.45 & 39.10 & 0.09 & 0.08 \\
\hline Portugal & 15 & 68.99 & 30.90 & 0.35 & 0.09 \\
\hline Slovakia & 14 & 2.65 & 2.38 & 0.06 & 0.03 \\
\hline Spain & 19 & 266.86 & 153.31 & 0.24 & 0.08 \\
\hline Sweden & 15 & 313.00 & 92.87 & 0.81 & 0.15 \\
\hline Switzerland & 11 & 754.27 & 139.54 & 1.82 & 0.13 \\
\hline United Kingdom & 19 & 3172.61 & 993.67 & 1.51 & 0.25 \\
\hline United States & 19 & 13393.62 & 2943.81 & 1.10 & 0.12 \\
\hline
\end{tabular}


Table 15: Instrumental variables analysis. The table contains OLS and 2SLS regression coefficients. An observation is a country-industry-year pair. The endogenous variable is the annual growth rate of production, value added, labor costs, and total employment (as defined by OECD). The exogenous variables are an indicator for positive PE activity over the previous five years at the country-industry level $\left(P E_{5}\right)$, and country-industry and industry-year fixed effects, as indicated. The 2SLS specifications in columns (3) and (5) use the fraction of assets held by domestic institutional investors to GDP as instruments for PE in the first stage. Specifications in columns (2) and (4) use a first stage where the instrument is interacted with industry indicators to allow for differential effects of the instrument at the industry level. Robust standard errors are presented in parentheses. Statistical significance at the 1\%, 5\% and $10 \%$ levels are indicated by $* * *, * *$, and $*$, respectively.

Panel A: Production and Value Added

\begin{tabular}{lcccccc}
\hline & $(1)$ & $(2)$ & $(3)$ & $(4)$ & $(5)$ & $(6)$ \\
& $\begin{array}{c}\text { Production } \\
\text { (gross } \\
\text { output) }\end{array}$ & $\begin{array}{c}\text { Production Production } \\
\text { (gross } \\
\text { output) }\end{array}$ & $\begin{array}{c}\text { (gross } \\
\text { output) }\end{array}$ & $\begin{array}{c}\text { Value } \\
\text { Added }\end{array}$ & $\begin{array}{c}\text { Value } \\
\text { Added }\end{array}$ & $\begin{array}{c}\text { Value } \\
\text { Added }\end{array}$ \\
& OLS & 2 SLS & 2 SLS & OLS & 2SLS & 2SLS \\
& & & & & & \\
\hline PE $_{5}$ & $0.863^{* * *}$ & $1.416^{* *}$ & $1.316^{* *}$ & $0.881^{* * *}$ & $1.808^{* *}$ & $1.887^{* *}$ \\
& $(0.209)$ & $(0.588)$ & $(0.622)$ & $(0.255)$ & $(0.711)$ & $(0.751)$ \\
C-I FE & Yes & Yes & Yes & Yes & Yes & Yes \\
I-Y FE & Yes & Yes & Yes & Yes & Yes & Yes \\
\hline Observations & 8,134 & 7,026 & 7,026 & 8,173 & 7,051 & 7,051 \\
\hline
\end{tabular}

Panel B: Labor Costs and Total Employment
(1)
(2)
(3)
(4)
(5)
(6)

Labor Costs Labor Costs Labor Costs Number of Number of Number of (compensation(compensation(compensation Employees EmployeesEmployees of employees) of employees) of employees)

\begin{tabular}{lcccccc} 
& OLS & 2SLS & 2SLS & OLS & 2SLS & 2SLS \\
& & & & & & \\
\hline PE $_{5}$ & $0.905^{* * *}$ & $2.316^{* * *}$ & $2.542^{* * *}$ & $0.777 * * *$ & $0.613^{*}$ & $0.722^{* *}$ \\
& $(0.180)$ & $(0.457)$ & $(0.484)$ & $(0.127)$ & $(0.327)$ & $(0.346)$ \\
C-I FE & Yes & Yes & Yes & Yes & Yes & Yes \\
I-Y FE & Yes & Yes & Yes & Yes & Yes & Yes \\
\hline Observations & 7,885 & 6,828 & 6,828 & 7,928 & 6,913 & 6,913 \\
\hline
\end{tabular}

